\title{
抗毛髪ケラチン抗体の作製とその特性： 牛初乳ならびに常乳の利用
}

\author{
海老名卓三郎・太田 実* ·打和秀世** 村、上梅司 ${ }^{* *}$ \\ 宮城県立がんセンター研究所, 名取市 981-12 \\ *東北大学莀学部附属農場, 宮城䀠鳴子町 989-67 \\ **鐘紡(株)生化学研究所，小田原市 250
}

(1993. 7. 5 受付)

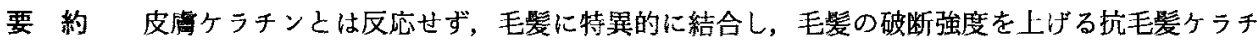
ン抗体を含も初乳ならでに常乳を免度牛に産生させた，人毛髪ケラチン $50 \mathrm{mg}$ を出産 60 日前のホルス タイン牛に筋肉内に注射し，(2〜3) 週間後に同抗原を乳房内または乳房りンパ節附近に投与すると, 血 中抗体価ならびに初乳中の毛髪ケラチンに対する抗体価は $10^{5} に$ 上昇した。この時，免疫牛一頭の初乳 中に（1 1.5) kgのIgG を産生することが出来た，さらにこれらの免疫牛に分婏 2 3 3月後ケラチン

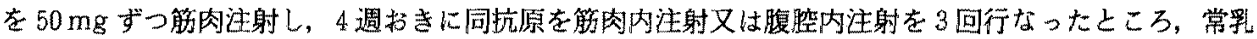
中に初乳之同等の比活性を持った抗体が出来ることを見出した，常乳では 300 日間售乳することがで き、全体では（4～5) kg のIgGを得ることができる．これより，初乳に加えて常乳を抗体生産に利用す ることが可能となった。
\end{abstract}

日畜会報，65 (6) : 580-590，1994

われわれは先の報告 ${ }^{(6)}$ で，毛髮ケラチンに対する抗体 が皮虞ケラチンに結合せず，毛坛に抗原・抗体反応で結 合すること，そしてこの結合によって毛㰮損傷の改善が 期待できることを報告した。しかしながら使用した抗体 はウサギ隹清由来であり，これから得られる抗体の䡒は

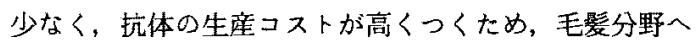
の奏用化は困難であった。

抗体の大量生産方法については, 牛初乳 ${ }^{5-7)}$, 牛常乳, および鶏卵黄畐を利用する方法が考えられる。中でも EBINA らが報告している牛初乳由来抗体を利用した口夕 ウィルス下麻症の予防，ならびに治療法の発見 ${ }^{5,7.9)}$ と実 用的底用 ${ }^{10}$ 结その可能性を示している。

促来牛の初乳は常乳之成分が異なるため，子牛に与天

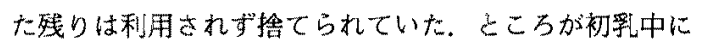
は IgG, IgA, $\operatorname{Ig} M$ が常乳に比して数 10 倍から 100 倍以 上多く含まれ，特に IgA は蛋白分解酵素に抵抗性で，ウ イルスに対する中和抗体価の比活性手高いことが分加っ た5,6).そこで今まで捨てられていた初乳を利用すべく， われわれ娃娠 8 力のホルスタイン乳牛に麻翏ウイル $ス^{6)}$ やトロタウイルス ${ }^{7,10)}$ を免疫し，この初釈の抗ウ
イルス活性を証明してきた。これらのことは、牛初乳を 抗体大量生産に利用することの価値が高いことを示して いる.

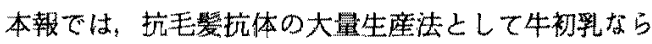
びに常乳の利用に注目し，詳細な免接条件まよび得られ た抗体の毛髪に及ぼす効果を検討した。 その結果，牛初 釈ならびに常乳から得られた抗体は，ウサギ血清由来抗

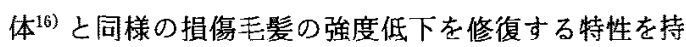
ち，且っ大量に生産できることを見出したので報告す る.

\section{材料および方法}

\section{1. 抗原}

抗原の謂製は，BADENららの方法に隼じて们なった。

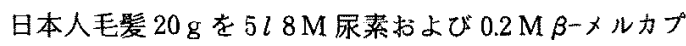

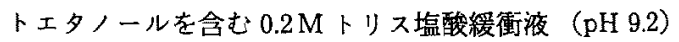
で, 空素気流下 $50^{\circ} \mathrm{C}, 1$ 時間抽出後に摩研した。遠心後

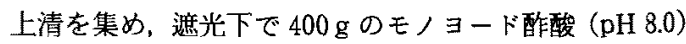
を加え， 1.5 時間室温で穏やかに摜拌した，反㐫は $\beta$ ○メ ルカプトェタノールを添加して停止した，水で逶析後， 


\section{牛乳由来毛裝抗体の作製之特性}

$1 / 4$ 容量の $1 \mathrm{M} \mathrm{KCl}$ を含む $0.5 \mathrm{M}$ 酢酸楥衝液（pH 4.1） を添加し，等電点沈湃する区分を集めた。これを生理食 塩水に溶解後， $0.2 \mu \mathrm{m}$ 孔の膜を用いて滤過し，限外濾過 濃縮して抗原溶液 $200 \mathrm{ml}(20 \mathrm{mg} / \mathrm{m} l)$ を得た.

\section{2. 兔疫方法}

常法に送い，2本の注射筒を用いて抗原溶液と完全フ ロイントアジュバント（FCA）または不完全フロイント アジェバント（FIA）(以上 Difco laboratories 社, ミシ ガン）を混和し，油中水 (W/O) 型の乳化物とした．投 与抗原量は，牛1頭当たり皮下注射の場合 $(10 \sim 200)$ $\mathrm{mg}$ /回, 筋肉内注射の場合 $(10 \sim 50) \mathrm{mg}$ /回, 乳腺内，リ ンパ節内、腹垫内接種の場合 $50 \mathrm{mg} /$ 回とした。

\section{3. 乳牛}

妊娠ホルスタイン牛 17 頭, 年齢は $(3 \sim 7)$ 年, 体重 (530 690) kg を用いた. このうち牛No. 605，624， 575,598 は 2 年にわたり免疫した. 牛 No. 500 は分婏後 3 日目にリンパ節内に追加免疫した。

供試牛は, 毎月 1 回体重を测定し，健康状態を観察し た。 また，分凂後は每月捽乳最を計量した。

\section{4. 抗体価湘定}

血清中及び乳中の抗体洒の測定には，酵素免疫測定法 (Enzyme-linked immunosorbent assay ; ELISA) を 用いた. ELISA は, 96 穴プレートの各穴に $3.9 \mathrm{ng} / \mathrm{ml}$ の 抗原を $0.1 \mathrm{~m} l$ 吸着反応させ， 2 次抗体としてペルオキシ ダーゼ標識抗牛 IgG 抗体 (E.Y. Laboratories 社, カリ フォルニア）を用いた間接抗体法で行ない，抗体価を測 定した. 比活性は単位抗体濃度当りの抗体価として算出 Lた.

\section{比活性 $=[$ 抗体価 (Titer) $/ \mathrm{IgG}$ 濃度 $](\mathrm{l} / \mathrm{g})$}

5. 免疫グロブリン量測定

血清中妨よび乳中の免疫グロブリン量（IgM， IgA， IgG, IgG,$\left.I g G_{2}\right)$ の测定は，一元放射状免疫拡散法 (Single radial immunodiffusion; SRID) を用い, SRID キット (Binding Site 社,バーミンガム) を使用 Lt.

\section{6. 脱脂操作}

摧乳した初乳は日量約 $4 l$ を子牛に与え，残りを $20 l$

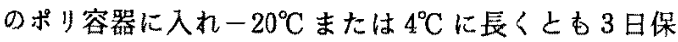
存しておいた．脱脂操作は，クリームセパレーターを用 い，個体別に分画操作を行なった。

\section{7. 抗体の精製}

脱脂乳に $0.1 \mathrm{~N}$ 笽酸を添加して $\mathrm{pH} 4.5$ にしカゼイン を沈滩除去した，得られた上清を中和した後，33\%飽和 になるように硫酸アンモニウムを加え，抗体を塩折させ た，遗心分離して得た抗体は生理食塩水に溶解し，この
硫安塩折をさらにもう一度行なった. $10 \mathrm{mM}$ リン酸緩 衝液（pH 7.5）にて透析し，蛋白質として約 $60 \mathrm{~g}$ 相当量 局湲衝液にて平衡化した Diethylaminoethyl (DEAE) セルロースカラム（值径 $7.2 \mathrm{~cm} \times 50 \mathrm{~cm}$ 、流速 $20 \mathrm{ml} / \mathrm{min}, 4^{\circ} \mathrm{C}$ ) に供した，同緩衝液で非吸着画分を溶 出した. $50 \mathrm{mM}$ 塩化ナトリウム含有同緩衙液で溶出す る画分を集めた. Sodium Dodecylsulfate (SDS) 電気 泳動，およびゲル濾過分析法で調べた抗体の純度は $90 \%$ 以上であった。

さらにこの画分を抗原として用いた毛琹ケラキンを結 合させた担体（アフィゲル 15）を使ったアフィニティー クロマトグラフィーに供した. 毛珑ケラチンとアフィゲ ル15の結合は，3-(N-Morpholino) propanesulfonic acid (MOPS) 䌅衝液 (pH 7.5) 中, ゲル $1 \mathrm{ml}$ 当たり 8

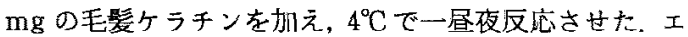
夕ノールアミン $\mathrm{HCl}$ ( $\mathrm{pH} \mathrm{8.0)}$ で末反応活性基のプロッ キングを行なったここのゲルをPBS (Phosphate-buffered saline, $\mathrm{NaCl} 8.0 \mathrm{~g} / l, \mathrm{KCl} 0.2 \mathrm{~g}$ / $l, \mathrm{Na}_{2} \mathrm{HPO}_{4}-12 \mathrm{H}_{2} \mathrm{O} 2.9 \mathrm{~g} / l, \mathrm{KH}_{2} \mathrm{PO}_{4} 0.2 \mathrm{~g} / l$ (pH 7.2)) で洗浄, 平衡化し，アフィニティークロマトグラフィー （直径 $1 \mathrm{~cm} \times 20 \mathrm{~cm}$, 流速 $20 \mathrm{ml} / \mathrm{h}, 4^{\circ} \mathrm{C}$ ) を行った. DEAE 精製抗体 $7 \mathrm{~g}$ 相当量をカラムに供し, 非吸着画分

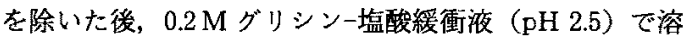
出した，抗体伍の収率は $100 \%$ で定量的に回収されてお り，比活性は 100 倍に上がり特異的な抗体のみからなる 抗毛髪ケラチン抗体を得た。

対照抗体は, 非免疫牛初乳を用いて同様の方法で DEAEセルロースカラムイオン交換クロマトグラ フィーを行ない，その吸着画分から得た標品をすってし t.

\section{8. 毛䯳結合試験}

男性（26才）の正常毛髮の凍結切片 $(6 \mu \mathrm{m})$ をぜラチ ンを塗布した無蛍光スライドグラスにパラホルムアルデ ヒド固定した．アフィニティークロマトグラフィーで精 製した抗毛䯽ケラチン抗体あるいは対照抗体を，10\%ウ サギ血清含有 PBS で $0.5 \mathrm{mg} / \mathrm{ml}$ に稀瀵し，室温で 30 分 間反応させた. PBSで洗浄後，2次抗体としてのローダ ミン標識ウサギ抗牛イムノグロブリン抗体を室温を゙ 30 分間反它させた. PBSグリセリンで封入し，OLYMPUS 落射型䖵光顕微鏡で観察した。

9. 皮膚ケラチンの反応性試験

毛髪由来のケラチンと皮䖉由来のケラチン(シグマ 社, ミズーリー, K 0253) 各々50ngを, SDS-10\%ポリ アクリルアミドゲル電気泳動法にて展開しこれを TowBIN ら ${ }^{14)}$ の方法に従って蛋白質をニトロセルロース 
海老名・太田・打和・村上

膜(ミリポア・リミテッド社製) に転写し， $1.7 \mu \mathrm{g} / \mathrm{ml}$ の DEAEセルロースイオン交換クロマトグラフィーで調 製した抗毛憶ケラチン抗体を使い，ウエスタン・ブロッ ティングを行なった。 なお，Coomassie Brilliant Blue （CBC）染色を対照亡した。

10. 毛裝の破断强度測定

ブラッシングで 1 万回処理した女性の毛髪 $1 \mathrm{~g}$ を束ね て毛髪サンプルとした. DEAEセルロースイオン交換ク
ロマトグラフィーで調製した进裂ケラチン莯体をPBS で $0.01 \% ， 0.1 \% ， 1 \%$ K溶解させ，この溶液 $10 \mathrm{ml}$ K $30^{\circ} \mathrm{C}$ で 1 時間毛㰮サンプルを浸漬した，流水中で 10 分 間洗浄した後, $45^{\circ} \mathrm{C}$ で風乾した. 毛束より $70 \sim 80 \mu \mathrm{m}$ の 太さの毛珑 50 本を無作為に取り出し, へアテスター（L. B.ケミカル社製，東京)を用いて破断強度を測定した。 対照抗体として免疫していない牛初乳より精製した抗体 溶液を用い，PBSに浸漬したむのに対する統計的比皎

Table 1. Hair keratin immunization groups

\begin{tabular}{|c|c|c|c|c|c|}
\hline \multirow{2}{*}{$\begin{array}{c}\text { Group } \\
\text { No. }\end{array}$} & \multirow{2}{*}{$\begin{array}{l}\text { Cow } \\
\text { No. } \\
493\end{array}$} & \multicolumn{2}{|c|}{ Inoculum size } & \multirow{2}{*}{$\begin{array}{c}\begin{array}{c}\text { Route of } \\
\text { inoculation }\end{array} \\
\mathrm{sc}\end{array}$} & \multirow{2}{*}{$\frac{\text { Time of inoculation }}{8 \text { weeks before parturition }}$} \\
\hline & & 1st dose & $: \quad 10 \mathrm{mg}+\mathrm{FCA}$ & & \\
\hline & & $2 \mathrm{nd} \sim 6 \mathrm{th}$ & $: 10 \mathrm{mg}+\mathrm{FIA}$ & sc & 10 days intervals \\
\hline & \multirow[t]{3}{*}{614} & 1st dose & $: \quad 10 \mathrm{mg}+\mathrm{FCA}$ & $\mathrm{sc}$ & 8 weeks before parturition \\
\hline & & $2 \mathrm{nd} \sim 4$ th & $: 10 \mathrm{mg}+\mathrm{FIA}$ & $\mathrm{sc}$ & 10 days intervals \\
\hline & & 5 th $\sim 6$ th & : $10 \mathrm{mg}+\mathrm{FIA}$ & $\mathrm{im}$ & 10 days intervals \\
\hline & \multirow[t]{2}{*}{525} & 1st dose & $: \quad 50 \mathrm{mg}+\mathrm{FCA}$ & sc & 8 weeks before parturition \\
\hline & & $2 \mathrm{nd} \sim 6 \mathrm{th}$ & : $50 \mathrm{mg}+\mathrm{FIA}$ & $\mathrm{sc}$ & 10 days intervals \\
\hline & \multirow[t]{3}{*}{605} & 1 st dose & $: \quad 50 \mathrm{mg}+\mathrm{FCA}$ & sc & 8 weeks before parturition \\
\hline & & $2 \mathrm{nd} \sim 4$ th & $: 50 \mathrm{mg}+\mathrm{FIA}$ & $\mathrm{sc}$ & 10 days intervals \\
\hline & & 5 th $\sim 6$ th & $: 50 \mathrm{mg}+\mathrm{FlA}$ & im & 10 days intervals \\
\hline 2 & 527,617 & $1 s t \sim 3 r d$ & $: 200 \mathrm{mg}+\mathrm{FCA}$ & $\mathrm{sc}$ & 10 days intervals from 40 days before parturition \\
\hline \multirow[t]{5}{*}{3} & \multirow[t]{2}{*}{500} & 1st dose & $: \quad 50 \mathrm{mg}+\mathrm{FCA}$ & im & 8 weeks before parturition \\
\hline & & 2nd dose & $: \quad 50 \mathrm{mg}+\mathrm{FIA}$ & $\mathrm{IMm}$ & 2 weeks after 1 st inoculation \\
\hline & \multirow[t]{3}{*}{612} & 1st dose & $: \quad 50 \mathrm{mg}+\mathrm{FCA}$ & im & 8 weeks before parturition \\
\hline & & 2nd dose & : $50 \mathrm{mg}+$ FIA & $\mathrm{IMm}$ & 2 weeks after 1 st inoculation \\
\hline & & 3rd dose & $50 \mathrm{mg}+\mathrm{FIA}$ & im & 10 days before parturition \\
\hline \multirow[t]{3}{*}{4} & \multirow[t]{3}{*}{464,583} & 1st dose & $: \quad 50 \mathrm{mg}+\mathrm{FCA}$ & im & 8 weeks before parturition \\
\hline & & 2nd dose & $: 50 \mathrm{mg}+\mathrm{FIA}$ & IMm & 2 weeks after 1 st inoculation \\
\hline & & 3rd dose & $: \quad 50 \mathrm{mg}+\mathrm{FIA}$ & $\mathrm{IMrn}$ & 4 weeks after 1 st inoculation \\
\hline \multirow[t]{2}{*}{5} & \multirow[t]{2}{*}{575,598} & lst dose & $: 50 \mathrm{mg}+\mathrm{FCA}$ & $\mathrm{im}$ & 8 weeks before parturition \\
\hline & & 2nd dose & $: 50 \mathrm{mg}+\mathrm{FIA}$ & ILn & 3 weeks after 1 st inoculation \\
\hline \multirow[t]{2}{*}{6} & \multirow[t]{2}{*}{605} & immunize & $: 50 \mathrm{mg}$ & & 1 year before (see group 1) \\
\hline & & bst & : $50 \mathrm{mg}+\mathrm{FIA}$ & $\mathrm{IMm}$ & 8 weeks and 4 weeks before parturition \\
\hline \multirow[t]{2}{*}{7} & \multirow[t]{2}{*}{500} & immunize & $: 50 \mathrm{mg}$ & & (see group 3) \\
\hline & & bst & : $50 \mathrm{mg}+\mathrm{FIA}$ & ILn & 3 days after parturition \\
\hline \multirow[t]{6}{*}{8} & 575,598 & bst & $: \quad 50 \mathrm{mg}+$ FIA & $\mathrm{im}$ & 1 month intervals, 4 times \\
\hline & 605.624 & bst & $: 50 \mathrm{mg}+\mathrm{FIA}$ & ip & 1 month intervals, 4 times \\
\hline & \multirow[t]{2}{*}{585,608} & 1st dose & $: 50 \mathrm{mg}+\mathrm{FCA}$ & im & \\
\hline & & bst & $: 50 \mathrm{mg}+\mathrm{FIA}$ & $\mathrm{im}$ & 1 month intervals, 3 times \\
\hline & \multirow[t]{2}{*}{620.625} & 1st dose & $: \quad 50 \mathrm{mg}+\mathrm{FCA}$ & im & \\
\hline & & bst & : $50 \mathrm{mg}+\mathrm{FIA}$ & ip & 1 month intervals, 3 times \\
\hline
\end{tabular}

$\mathrm{sc}=$ subcutaneously $\mathrm{im}=$ intramusculary $\mathrm{IMm}=$ intramammarily $\mathrm{ILn}=$ into mammary lymph node region ip=intraperitoneally 
$(t$-検定) を行った。

結果

\section{1. 免疫方法の検䚯}

(1) 牛初乳の利用

試験に供した牛斿よび免疫方法を表 1 にまとめた。実 駼 1 では奸娠 8 カ月のホルスタイン牛 4 頭を使い, 10 ま たは $50 \mathrm{mg}$ の毛珓ケラチンを 10 日間間隔で 6 回皮下お よび筋肉内注射した。初回のみFCAを使い，以降は FIA を使用したが，初乳中に抗体洒 $10^{4}$ 以上の高い抗体 を得ることができなかった，次に実験 2 では妊娠 8 力月 の牛 2 頭を使い投与抗原量を $200 \mathrm{mg}$ に増加し，す心゙て
FCA 在用いて 10 日間隔で 3 回皮下投与した，しかし血 中の抗体価もを机程上昇せず，初乳の抗体価屯高くな かった。

そこで実験 3 では TZIPORI ら ${ }^{15)}$ の方法に準じて, 出産 予定日9 60 日前に FCA と共に抗原 $50 \mathrm{mg}$ 筋肉内注 射した後，2週間目にFIA と共に乳房内に注射し兔疫し た (牛 No. 500). 1 頭はさらに出産予定日の10日前筋肉 内注射で追加免疫した (牛 No. 612). 投与抗原量はいず れも50 mg とした. その結果，表 2 に示すように血中の 抗体価が 1 頍は $10^{5}$ を越元，他の1頭す $4.7 \times 10^{4}$ まで上 昇した，ただし，初回免疫から6週目の血中抗体価が極 大值 (牛 No. $500: 2.0 \times 10^{5}$, 牛 No. $612: 9.9 \times 10^{4}$ ) を示

Table 2. Hair keratin antibody titers and contents of immunoglobulins in colostrum and serum of cows immunized into a mammary gland

\begin{tabular}{|c|c|c|c|c|c|c|c|c|c|}
\hline \multirow{2}{*}{$\begin{array}{l}\text { Cow } \\
\text { No. }\end{array}$} & \multirow{2}{*}{\multicolumn{2}{|c|}{ Sample }} & \multirow{2}{*}{$\underset{(\mathrm{kg})}{\text { Volume }}$} & \multirow{2}{*}{$\begin{array}{l}\text { Protein } \\
(\mathrm{g} / l)\end{array}$} & \multicolumn{3}{|c|}{ Immunoglobulin $(\mathrm{g} / \mathrm{l})$} & \multirow{2}{*}{ Titer } & \multirow{2}{*}{$\begin{array}{l}\text { Specific activity } \\
\text { Titer/IgG }(l / g)\end{array}$} \\
\hline & & & & & $\operatorname{IgM}$ & $\lg A$ & $\operatorname{IgG}$ & & \\
\hline \multirow[t]{5}{*}{500} & serum & pre-immu, & & & & & & $4.2 \times 10^{3}$ & \\
\hline & & calving & & & 2.61 & 0.19 & 38.0 & $1.9 \times 10^{5}$ & 5,000 \\
\hline & colostrum & calving & 10.4 & 148 & 3. 39 & 0.89 & 85.8 & $1.7 \times 10^{6}$ & 20,000 \\
\hline & & 2nd day & 7.3 & 85.4 & 1.87 & 0.46 & 31.1 & $7.5 \times 10^{5}$ & 24,000 \\
\hline & & 3rd day & 7.8 & 55.8 & 0.64 & 0.20 & 14.7 & $2.1 \times 10^{5}$ & 14,000 \\
\hline \multirow[t]{5}{*}{612} & serum & pre-immu. & & & & & & $6.6 \times 10^{3}$ & \\
\hline & & calving & & & 3.02 & 0.06 & 20.6 & $4.7 \times 10^{4}$ & 2,300 \\
\hline & colostrum & calving & 3.6 & 135 & 3.56 & 1.00 & 83.4 & $4.0 \times 10^{5}$ & 4,800 \\
\hline & & 2nd day & 7.5 & 62.8 & 1.36 & 0.29 & 19. 8 & $9.7 \times 10^{4}$ & 4,900 \\
\hline & & $3 r d$ day & 13.6 & 44.9 & 0.36 & 0.09 & 5.6 & $3.7 \times 10^{4}$ & 6,600 \\
\hline
\end{tabular}

Table 3. Hair keratin antibody titers and contents of immunoglobulins in colostrum and serum of cows immunized into a mammary lymph node

\begin{tabular}{|c|c|c|c|c|c|c|c|c|c|}
\hline \multirow{2}{*}{$\begin{array}{l}\text { Cow } \\
\text { No. }\end{array}$} & \multirow{2}{*}{\multicolumn{2}{|c|}{ Sample }} & \multirow{2}{*}{$\underset{(\mathbf{k g})}{\text { Volume }}$} & \multirow{2}{*}{$\begin{array}{l}\text { Protein } \\
(\mathrm{g} / l)\end{array}$} & \multicolumn{3}{|c|}{ Immunoglobulin $(\mathrm{g} / l)$} & \multirow{2}{*}{ Titer } & \multirow{2}{*}{$\begin{array}{l}\text { Specific activity } \\
\text { Titer/lgG }(l / \mathrm{g})\end{array}$} \\
\hline & & & & & $\lg \mathrm{M}$ & $\operatorname{Ig} \mathrm{A}$ & $\operatorname{lgG}$ & & \\
\hline \multirow[t]{5}{*}{575} & serum & pre-immu. & & & & & & $6.4 \times 10^{3}$ & 200 \\
\hline & & calving & & & & & & 2. $1 \times 10^{5}$ & 10,600 \\
\hline & colostrum & calving & 6.0 & 174 & 5.85 & 0.11 & 104 & $1.6 \times 10^{6}$ & 15,400 \\
\hline & & 2nd day & 7.7 & 59.4 & 1.56 & ND & 19.6 & $3.0 \times 10^{5}$ & 15,300 \\
\hline & & 3rd day & 3.1 & 40.8 & 0.54 & $\mathrm{ND}$ & 7.9 & 1. $1 \times 10^{5}$ & 13,900 \\
\hline \multirow[t]{5}{*}{598} & serum & pre-immu. & & & & & & $1.5 \times 10^{3}$ & 50 \\
\hline & & calving & & & & & & $3.4 \times 10^{4}$ & 1,900 \\
\hline & colostrum & calving & 13.9 & 180 & 4.92 & 0.96 & 87.2 & 5. $4 \times 10^{5}$ & 6,200 \\
\hline & & 2nd day & 12.5 & 60.5 & 0.86 & 0.12 & 15.0 & $5.3 \times 10^{4}$ & 3,500 \\
\hline & & 3rd day & 14.7 & 37.6 & 0.28 & ND & 4.2 & $1.2 \times 10^{4}$ & 2,900 \\
\hline
\end{tabular}

ND : not detectable 
海老名 $\cdot 太$ 田・打和・村上

したものの，7週目以降出産時（牛 No. $500: 9$ 週目，牛 No. $612: 8.5$ 週目）まで穞やかな低下傾向がみられ，追 加免疫の侍期が至適でなかったことを示していた，得ら れた初乳中の抗体価す血中抗体価に相応した值が得られ た。な和初乳加ら得られるIgG 量は，1頭より（1１.5） $\mathrm{kg}$ が見込まれた。またこれまで 3 回の実験でいずれも 血中上り初乳中の比活性が数倍高く, 抗体の乳中への選 択的な移行が観察された。

さらに実験 4 では乳房内追加免疫による牛 No. 500 の 効果の再現性を確認すると共に，回数を2度（乳房内投 与は 2 週間後および 4 週間後) 行なうことによるさらな る効果をみた，その結果，2頭とも血中の抗体価がいず れも $10^{5}$ を越えブース卜効果を認め, 初乳中抗体の抗体 価も血中の抗体価之相応して上昇し, 比活性は 1 頭が $(17,600 \sim 4,800)$, 他の 1 頭が $(5,500 \sim 2,600)$ と牛 No. 500 と同様の結果を得, 乳房内投与の効果を確認した. ただし回数を 2 度行なうことによる顕著な効果は見られ なかった。

そこで実験 5 では乳房りンパ節への追加免疫の効果を 調べた（表 3)。出産予定日の 60 日前に FCA と共に 50 $\mathrm{mg}$ の抗原を筋肉注射し，3 週間後にFIA と共にリンバ 節付近に同量投与した．血中の抗体価からブースト効果 を諗め, 1 頭は $10^{5}$ を越元，初乳中抗体の比活性も血中の 抗体価と相応して 1 頭が $(15,000 \sim 13,000)$ ，他の 1 頭が $(6,200 \sim 2,900)$ と乳房内投与と同様の結果を得 (表 3$)$, 乳房りンパ節付近への効果を確認した。

いずれの免疫方法でる出産時での血中抗体価の減少が 認められたので，出産前後での血中 $\operatorname{IgG}_{1}$ および $\mathrm{IgG}_{2}$ 濃 度を測定した。結果を図 1 に示した， $\operatorname{IgG}_{1}$ 濃度は出産数 週間前上り急激な低下を諗如，出産時には半分以下に

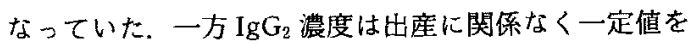
示した. このことより, 出産時の血中抗体価の隇少の一 因亡して，IgG

次に実験 6 では免疫経験牛への再免疫を試みた。1 年 前に免疫したNo. 605 牛（皮下および筋肉内注射）に出 産 2 力月前および 1 力月前に抗原を乳房内に注入した。 この結果, 少なくとも 1 年前に 1 度免疫した牛はこの毛

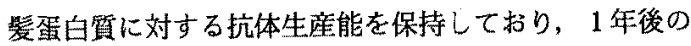
追加免厒に上り急激な抗体価の上昇を認的初乳中抗体の 比活性は（8,100～5,700）であった。ただし，この場合 2 回目のブースト効果は認ぬられなかった。

(2) 牛常乳の利用

次に実験 7 では牛 No. 500 を使って, 分婏後 3 日目に FIA 上共にリンパ節内に $50 \mathrm{mg}$ 毛髪ケラチンを追加免 疫し常乳利用の可否を検討した，その結果図 2 に示すよ

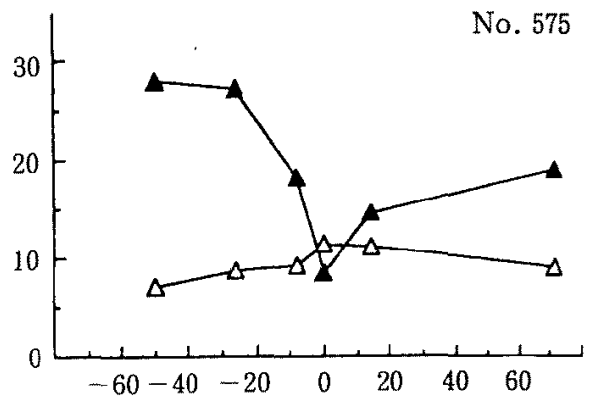

0
0
5
0
0
0
5
0
5
0
0
0
0
0
5
0
0
0
0
0

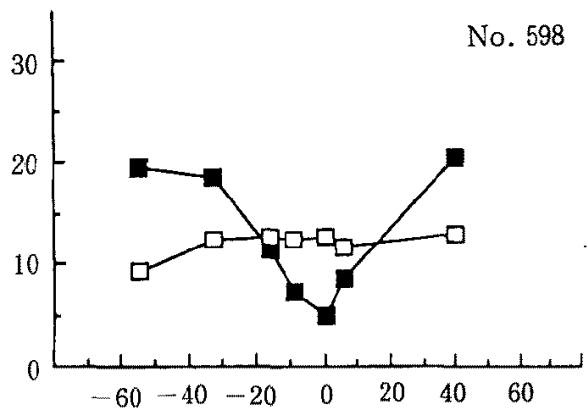

No. 500

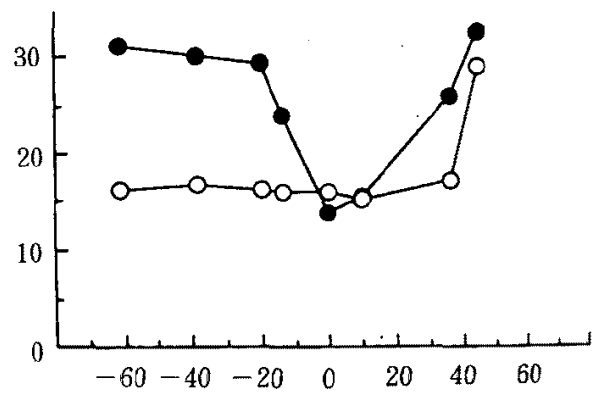

Days pre- or post-calving

Fig. 1. Changes in the concentrations of $\mathrm{IgG}_{1}$ and $\mathrm{IgG}_{2}$ in serum associated with calving. Cow No. $598\left(\square: \operatorname{IgG}_{1}, \square: \operatorname{IgG}_{2}\right.$ ), No. $575\left(\boldsymbol{\Delta}: \operatorname{IgG}_{1}\right.$, $\left.\triangle: \mathrm{IgG}_{2}\right)$, No. $500\left(\bigcirc: \mathrm{IgG}_{1}, \mathrm{O}: \operatorname{IgG}_{2}\right)$

うに常乳中にも初乳と同様の高い此活性を持った机毛髪 ケラチン抗体を得ることが出来た，すなわち追加免疫す ることにより初乳だけでなく常乳です抗体を生産するこ とが出来ることが分かった。

そこで前年に免度してある感作牛と，兔疫していない 非感作牛を使い毛髮ケラチンを $50 \mathrm{mg}$ ずつ, 分挽後（2 〜3）力月にほぼ 4 週扔きに筋肉内（im），ならびに腹腔 内（ip）に 4 回免疫したところ，図 3 (A) に示すように 感作牛では最初から高い抗体価を得ることが分った。一 


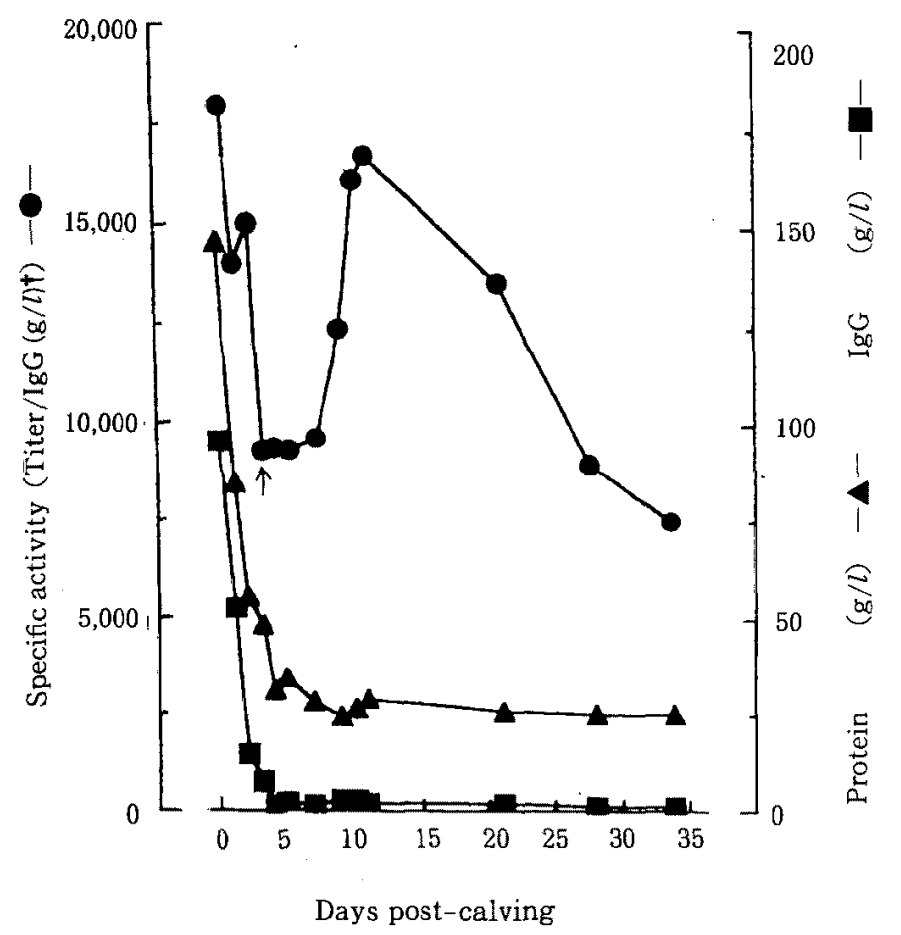

Fig. 2. Hair keratin antibody titers of IgG in the milk from the cow immunized after calving.

$\uparrow$ : booster injected into a mammary lymph node region

方非感作牛では图 3 (B) に示す上うに, 3 回免疫後から 抗体価が上昇することが分かった. 常乳は 1 泌乳期に約 $6,500 \mathrm{~kg}$ 生産されるので, 常乳には IgG が (4〜5) kg 含 まれることになる。

(3) 牛に与える免度の副作用

免疫をした牛の体重の推移, 分婏の状況, 子牛の健康 状況及び泌乳量等について異常は認められず，筋肉内ま たは皮下注射の後，局所に軽度の腫脹が見られること以 外には臨床的に異常は認められず，初乳ならびに常乳を 得ることが出来た。

\section{2. 蛍光抗体法に上る抗体之毛髪との結合}

図4に結果を示す之おり，対照抗体は毛琶之は反応せ

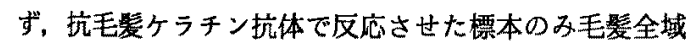
にわたり蛍光発色が観察され，免疫抗体が毛鬉のしかす 角質化した毛珑 (毛幹部)に結合することを認めた。

3. 沉体の毛髪ケラチンとの結合

牛抗毛髪ケラチン抗体が毛辰に特異的であるかどうか を，毛珑由来のケラチンと皮痛由来のケラチンに対する 抗体の反応性をウェスタン・ブロッティング法を用いて 検査した (図5)。これにより，牛初乳から得られた抗毛
髪ケラチン抗体は皮唐ケラチンと反応せず，毛髪由来の ケラチンと特異的に反応していることが観察された。

4. 抗毛髪ヶラチン抗体処理毛髮の物性

毛瑟ケラチン免疫牛加ら得た粗抗毛裂ケラチン抗体と 対照抗体で処理した，人毛亨破断强度を比較した，図 6に示すように，免度牛の初乳から得た抗体はブラッシ ングの損傷により低下した毛䈠の強度を向上させた。 こ れに対し, 非免疫牛の初乳加ら得た抗体は，毛瑟の強度 に影響を与えなかった。

\section{考 察}

妊娠牛に免疫して効率良い抗毛髪ヶラチン抗体を産生 させるためには，初回免疫加ある程度 (4 週前後)の間 隔を開けた 1 度加ら 2 度の追加免度が適していた。牛の 免疫間隔については，本研究で使用した毛翇ケラチンの 様な蛋白質に関する知見にそしく，主としてウイルス及 び細菌についての研究に限られている。 ウイルス及び細 菌については，抗原とアジュバンドの組合せに奻じて， 免度間隔が 1 週間3,13) から 8 週間 ${ }^{152}$ で行われている。し 加し，同じ抗原についてあ研究者によって免疫間隔が異 

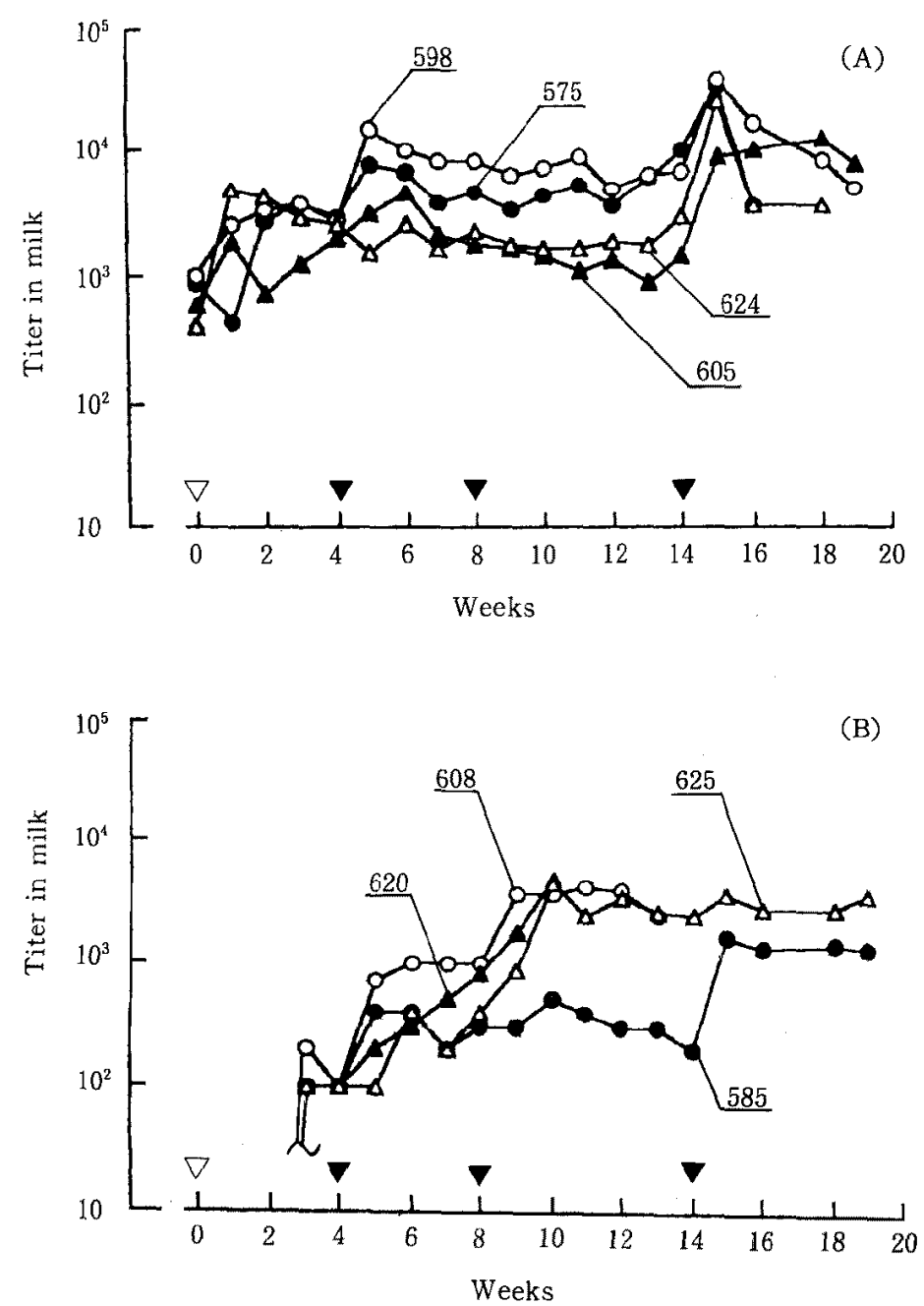

Fig. 3. Hair keratin antibody titers in milk.

(A) cows previously injected with the same antigen. O: Cow No. 598 (intramuscularly : im), : No. 575 (im), $\triangle$ No. 624 (intraperitoneally : ip),

$\Delta$ : No. 605 (ip), (B) non-immunized cows. $\bigcirc:$ No. 608 (im), $\bigcirc$ : No. 585 (im), $\triangle$ : No. 625 (ip), $\triangle$ : No. 620 (ip),

$\nabla:$ the time of immunization with keratin emulsified in FCA

$\nabla$ : the time of immunization with keratin emulsified in FIA

なり，一定の規则性はみられない。

さらに牛初乳に抗毛瑟ケラチン抗体孝効率よく産生さ せるためには，その追加免疫部位は乳房内あるいは乳房 リンパ節への投与が適していた（表 $2 ， 3$ )。この原因は未 だ確認できないが，今のところ局所免疫が同時に起こ り，効率よく抗体が産生されたと推定している.

乳房内投与は大腸菌 ${ }^{12)}$ 等で試みられている。これは， 出産の (4 5) 週間前の牛に 14 種の大腸菌を乳房内に投
与しここの牛から得られた初乳が大腸菌が原因の下瘚に 効果があることを臨床的に確かめているが, 本研究と比 較しうる抗体価についての知見はない，毛彭ケラチンが 大腸菌の様な感染力を持たず乳房内での抗原刺激が低い 上思われることから，今後解明がまたれる興味ある結果 である、また免疫経験のある牛への追加免度時期徒, 出 産 1 力月前でよいと思われた。

次にさらに大量の抗体を得るため常乳の利用の可否を 
A

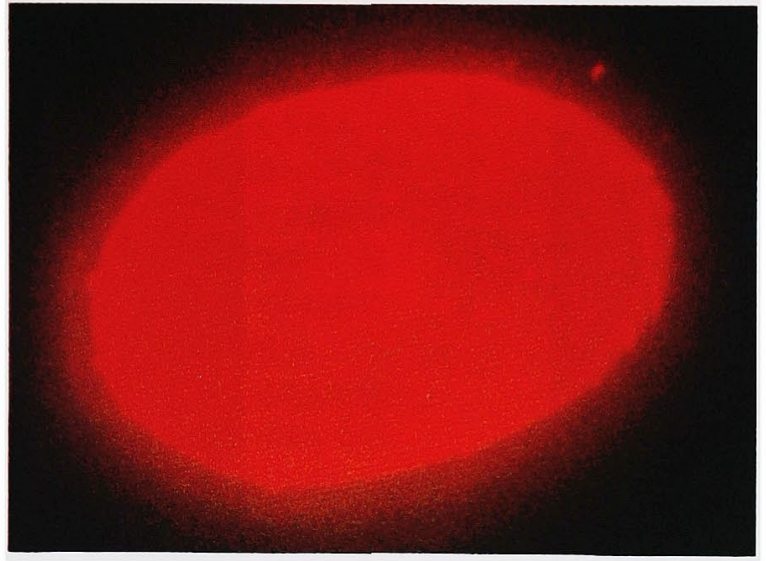

B

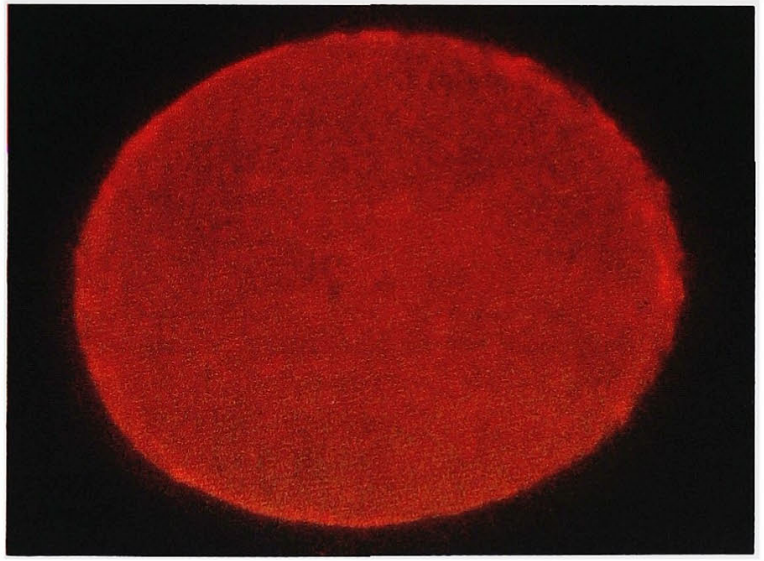

C

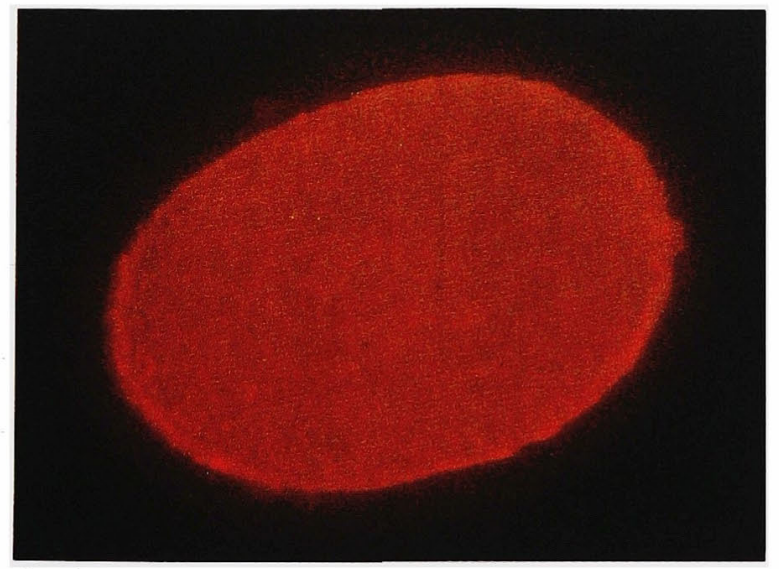

Fig. 4. Indirect immunofluorescence of cryotome sections of human hair with hair keratin antibody.

A : hair kerațin antibody, B : non-specific antibody, C : control (PBS) 
海老名・太田・打和・村上

A

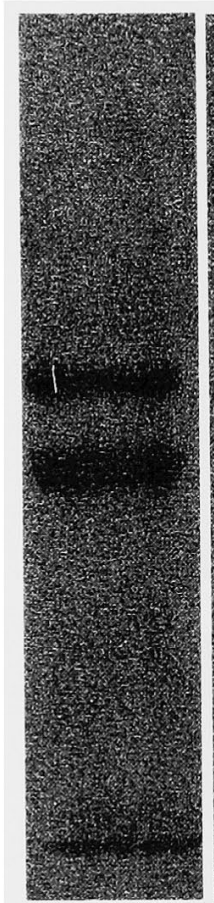

1

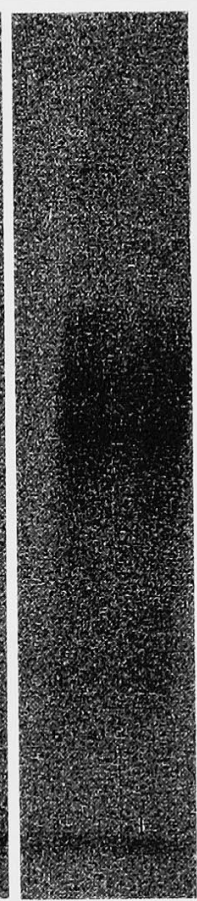

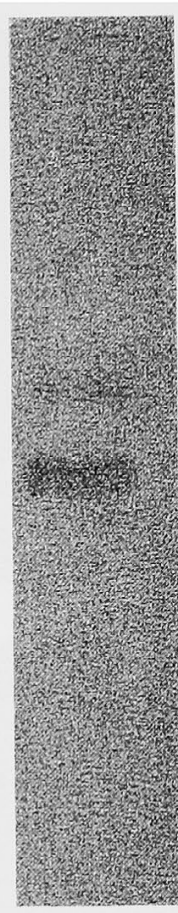

1
B

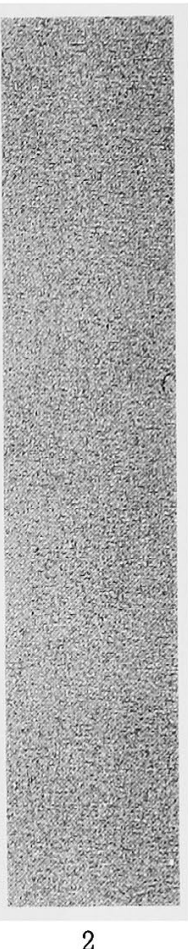

Fig. 5. Immunoblot analysis of human hair and epidermal keratins.

A : Coomassie Brilliant Blue, B : hair keratin antibody, 1 : human hair keratins, 2 : human epidermal keratins

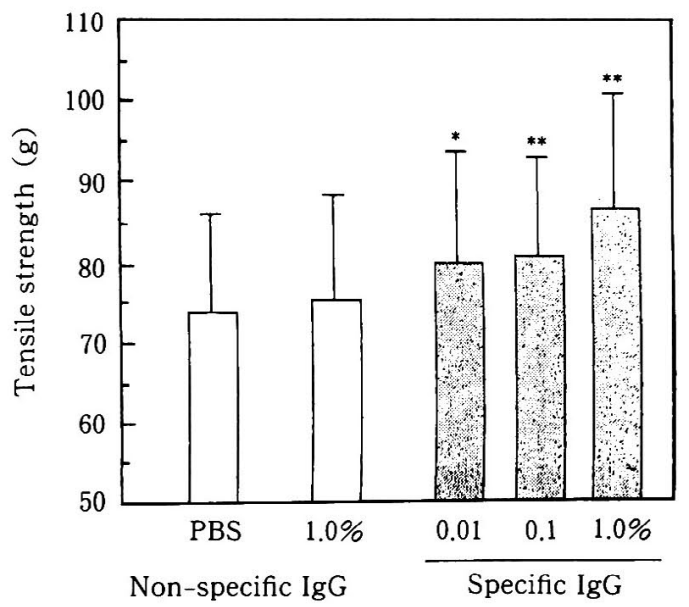

Concentration of immunoglobulin ${ }^{*} \mathrm{P}<0.05{ }^{* *} \mathrm{P}<0.01$

Fig. 6. Effect of hair keratin antibody on tensile strength.

Valus are means $\pm \mathrm{SE}$.
検討した．抗体の大量調製は，常乳中の IgG 濃度が初乳 の $(1 / 50 \sim 1 / 100)$ である ${ }^{4)}$ こ加ら, 出発物として常乳 はほとんど使われていない2). 従って，本研究では常乳 中の抗体の比活性（抗体価/IgG）を上げる方法を探索し た。 その結果， 1 年目に出産前に免疫してある感作牛に 関しては, 分婏 $(2 \sim 3)$ 月後ほぼ 1 力月毎に筋肉内又は 腹腔队に追加免疫することにより, 常に高い値の抗体価 を持った常乳を得ることが出来ることがわかった（図 3 A). ただし非感作牛ではなかなか高い值の抗体価を得 ることが出来なかった（図 3 B)。すすなわち 1 年目では初 乳を利用し， 2 年目からは追加免疫することにより, 常 乳も利用できることが分った。

得られた牛免疫抗体は蛍光抗体法により人毛髪に結合 し(図 4), ウエスタン・ブロッティング法で人皮唐ケラ チンには結合せず，人毛髪ケラチンとだけ特異的に結合 した（図 5)．ケラチンに関する知見から，ケラチンの 3 次構造は種間を問わず中央部に $\alpha$-ヘリックスを持ち, 両端に非へリックス部を持つ点で極めて類似している. ただし非へリックス部に皮䖉と毛髪で差異があり, 前者 
はグリシンとセリンを多く含み、後者はシステインとブ ロリンを多く含むことが知られている゙1). 随って共通部 である中央部 $\alpha$-ヘリックス部に対する抗体ができれば 皮虎と毛髪を区別できないし，非へリックス部の異なる 部位に対する抗体ができれ代区別できると考えられる。 実験結果から牛抗体は非へリックス部位を認識している のではないかと考えている. 今後, 毛髪ケラチン標品の 構造化学的知見之, 抗毛髪ケラチン抗体の認識部位の解 明が望まれる、さらにこの抗体はブラッシングの損傷に よって低下した人毛珑の強度を向上させた（図6）.

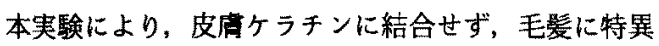
的に結合し，損傷で弱くなった毛㰮の物性を回復する特 性を持った抗毛髪ケラチン抗体の大量生産方法が見出さ れた.

\section{文献}

1) Baden, H.P., N. McGilvary, L.D. LEE, L. BAden and J. KuBilus, Comparsion of stratum corneum and hair fibrous proteins. J. Invest. Dermatol., 75 : 311-315. 1980.

2) BEDK, L.D., US patent, No. 4. 284. 623. 1981.

3) BRÜsso, W.H., H. Hilpert, I. W Alther, J. SiddTI, C. Mretens, and P. BachmanN, Bovine milk immunoglobulins for passive immunity to infantile rotavirus gastroenteritis. J. Clin. Microbiol., 25 : 982-986. 1987.

4) BUTLER, J.E. Synthesis and distribution of immunoglobulins. J. Amer. Vet. Med. Assoc., 163 795-798. 1973.

5) Ebina, T., A. Sato, K. Umezu, N. Ishida, S. Ohyama, A. Ohizumi, K. AiKawa, S. Katagiri, N. Katsushima, A. IMAI, S. Kit AOKA, H. SUZUKI and T. Konno, Prevention of rotavirus infection by cow colostrum containing antibody against human rotavirus. Lancet, 2 : 1029-1030. 1983.

6) Egina, T., A. Sato, K. Umezu, H. Aso, N. Ishida, H. Seki, T. Tsukamoto, S. Takase, S. Hoshi and M. OHTA, Treatmnet of multiple sclerosis with anti-measles cow colostrum. Med. Microbiol. Immunol, $173:$ 87-93. 1984.

7) Ebina, T., A. Sato, K. Umezu, N. Ishida. S. Ohyama, A. Ohizumi, K. Aikawa, S. Katagiri, N. Katsushima, A. ImaI, S. KitAoKa, H. SuzuKI and
T. Konno, Prevention of rotavirus infection by oral administration of cow colostrum containing antihuman-rotavirus antibody. Med. Microbiol. Immunol., 174 : 177-185. 1985.

8) Ebina, T., K. Tsukada, K. UmezU, M. Nose, K. Tsuda, H. Hatta, M. Kim and T. Yamamoto, Gastroenteritis in suckling mice caused by human rotavirus can be prevented with egg yolk immunoglobulin (IgY) and treated with a protein-bound polysaccharide preparation (PSK). Microbiol. Immunol, 34 : 617-629. 1990.

9) Ebina, T. and K. Tsukada, Protease inhibitors prevent the development of human rotavirus-induced diarrhea in suckling mice. Microbiol. Immunol., 35 : 583-588. 1991.

10) Ebina, T., M. Ohta, Y. Kanamaru, Y.Y. Osum and K. BABA, Passive immunizations of suckling mice and infants with bovine colostrum containing antibodies to human rotavirus. $\mathrm{J}$. Med. Virol., 38 : 117-123. 1992.

11）北島康雄, ケラチンの生化学, 生化学, $60 ： 546$ 551. 1988.

12) Mietens, C. and H. Keinhorst, Treatment of infantile $E$. coli gastroenteritis with specific bovine anti- $E$. coli milk immunoglobulins. Eur. J. Pediatr., 132 : 239-252. 1979.

13) TACKET, C.O., G. LOSONSKY, H. LiNK, Y. HOANG, P. GUESRY and H. HILPERT, Protection by milk immunoglobulin concentrate against oral challenge with enterotoxigenic Escherichia coli. N. Engl. J. Med., 318 : 1240-1243. 1988.

14) Towbin, H., T. Staehelin and J. Gordon, Electrophoretic transfer of proteins from poly. acrylamide gels to nitrocellulose sheets : Procedure and some applications. Proc. Natl. Acad. Sci. USA., 76 : 4350-4354. 1979.

15) Tzipori, S., D. Roberton and C. Chapman, Remission of diarrhoea due to cryptosporidiosis in an immunodeficient child treated with hyperimmune bovine colostrum. Br. Med. J., 293 : 1276-1277. 1986.

16）打和秀世・平野 真 - 小野靖子 ·村上梅司 $\cdot$ 太田 実・海老名卓三郎，抗毛髪ケラチン抗体の作成亡 その特性 (第 1 報)，兔抗体の利用，日本皮売科学 会䧴誌，印刷中，1994. 


\title{
Production of Anti-Hair Keratin Antibody and Its Characteristics : Utilization of Cow Colostrum and Milk
}

\author{
Takusaburo EBina, Minoru OHTA*, Hideyo UchiwA** \\ and Umeji MURAKAM*** \\ Research Institute Miyagi Cancer Center, Natori-shi $981-12$ \\ * Experimental Farm, Faculty of Agriculture, Tohoku University, \\ Narugo-machi, Miyagi-ken 989-67 \\ ** Kanebo Co. Ltd., Odawara-shi 250
}

\begin{abstract}
Eight-month pregnant Holstein cows were intramuscularly immunized with a reduced carboxymethylated human hair keratin preparation via a complete Freund's adjuvant, which was boosted into a mammary gland or a lymph node of the breast after 2-3 weeks. The cow colostrum, containing a high-titered anti-human hair keratin antibody, was obtained. Two months after delivery, the immunized cows were injected intramuscularly and boosted in tramuscularly or intraperitoneally with keratin protein 3 times at 4-week intervals, resulting in the production of cow's milk containing a high-titered antibody to human hair keratin. This significs the possibility of mass-producing the anti-human hair keratin antibody. This antibody is bound specifically to human hair keratin, not to epidermal keratin, and could improve the tensile strength of brushed human hair.
\end{abstract}

Anim. Sci. Technol. (Jpn.) 65 (6) : 580-590, 1994

Key words : Mass-production of antibodies, Cow colostrum, Hair keratin, Cow's mlik 